\title{
artículos
}

\section{Aullidos de chatarra. Una aproximación a Koyaanisqatsi (1982) a través de la música de Philip Glass y su imbricación ideológica}

José Valentín Serrano Garcia

Universidad de Málaga

PALABRAS CLAVE: Iconografía/ Música Contemporánea/ Estética

"En una época en la que el hombre corre el peligro de robotizarse, ahí está el arte para evitarlo". Oskar Kokoschka.

\section{RESUMEN}

Las transformaciones socioculturales de los últimos siglos han dejado su impronta en poéticas musicales que desempeñan un papel determinante en dicho proceso. Este trabajo intenta aproximar al lector a un film sin actores ni palabras -donde la imagen es la realidad y el sonido su descripción-, desentrañando el significado de la música mediante el análisis técnico básico, la lógica histórica que condujo a su existencia, el efecto perceptivo y la propia ideología del film.

ABSTRACT

The sociocultural transformations that have occured during the past centuries have left an undelible mark in musical language development. Such development has played a vital role in the sociocultural transformation process. This essay tries to explain a film that has neither actors nor words. Instead, it has images that depict reality and music that describes it. The aim of this work is therefore to explain the significance of music through a basic technical analysis, the historical process, the human perception towards the film and its outcoming ideology.

A mediados del siglo XVI, el Dr. Georg Bauer (agrícola) en su obra De re Metallica, un clásico de la tratadística renacentista, recogía el horror del rechinar del hierro a manera de argumento contra el trabajo en la mina. De hecho, siempre se había considerado el resonar metálico, por su frigidez extrema, como el sonido más desagradable e inhumano al que se podía estar expuesto. No es de extrañar pues

* SERRANO GARCÍA, José Valentín: "Aullidos de chatarra. Una aproximación a Koyaanisqatsi (1982) a través de la música de Philip Glass y su imbricación ideológica", Boletín de Arte n²8, Departamento de Historia del Arte, Universidad de Málaga,2007, págs. 479-506. 
que la música (y los instrumentos), incluso en épocas donde la moral imperante defendía la contención de las pasiones, se afanara en conservar cierto aroma orgánico y libertad de interpretación. La restauración decimonónica del canto gregoriano, sistemática en ejecución, o las fugas para teclado de J.S.Bach, frías pero exquisitas, eran las excepciones que confirmaban dicho principio.

Sin embargo, la veneración que las primeras vanguardias sintieron hacia el progreso, el maquinismo y la técnica ocasionó que en la década de 1910 Luigi Russolo concibiera una música ruidista a partir de sonidos preferentemente metálicos. A partir de ahí los avances se sucedieron en diversos círculos elitistas: Martenot, P. Schaeffer, P. Henry, B. Maderna o K. Stockhausen dieron los primeros pasos, abriendo nuevos campos de acción sonora. Mientras esta tendencia guardó una lógica experimental y se mantuvo recluida tras los muros de los laboratorios, el oyente prefirió seguir siendo fiel a su percepción auditiva humana, amante de todo tipo de matices, optando por las polirritmias de Stravinsky, los frescos aforismos de Webern, la explosión de percepciones de Schönberg, el bonito post-romanticismo o el vigoroso rock incipiente.

La eclosión de la música electrónica se daría a partir de la década de los 70 : los sintetizadores se multiplicaron, el sonido quedó encarcelado, los ritmos se repetían sin cambio alguno, las grandes sinfonías de Beethoven quedaban condenadas a ser escuchadas tras el filtro de Walter Carlos y la educación auditiva infantil quedaba en manos de la música de videojuegos; el ambiente acústico comenzaba, pues, a volverse grisáceo. Atrás quedaba, por ejemplo, la vibrante calidez del jazz. A pesar de todo, las consecuencias fueron aún más elocuentes: el rock, el heavy metal, los anuncios de televisión, o la propia música "clásica" contemporánea quedaron impregnados de aquellas nuevas características tímbricas. Ese timbre de áspero tacto marcaba las pautas de una nueva percepción sonora, un nuevo comenzar imbricado de la reinante situación cultural. De hecho, toda la realidad había sufrido una transformación paralela y similar.

Uno de los fenómenos que nos gustaría subrayar de esta revolución musical, fue la gran acogida que tuvo entre el público. Éste recibió con furor y pasividad aquello que habría sido considerado en el pasado como un atroz crimen al oído. De este modo nació una belleza monstruosa del sonido que, al fin y al cabo, solo era un elemento más de la monstruosa belleza de nuestras megalópolis, instituciones, autopistas, edificios, fábricas, ordenadores o microondas. ¿La afirmación de Kokoschka tiene hoy en día vigencia? ¿Es la belleza una droga capaz de hacernos olvidar una superestructura falaz y aberrante?

"Su autoalienación ha alcanzado un grado que le permite vivir su propia destrucción como un goce estético de primer orden"1. 
2 artículos Aullidos de chatarra. Una aproximación a Koyaanisqatsi...

Este es el punto de partida de Koyaanisqatsi.

1. UNA APROXIMACIÓN AL FILM: SIGNIFICADO Y CONTEXTO.

Koyaanisqatsi (1982) fue el primer largometraje del peculiar director Godfrey Reggio, un inusual autor cinematográfico que cuenta en su haber con un escaso número de películas a pesar de contar con más de 64 años. Nacido en Nueva Orleans, a los 14 años entró en la orden de los Hermanos Cristianos en donde permanecería anclado en la Edad Media, entregado al silencio y a la meditación, hasta que cumplió los 28 . Fue entonces cuando Reggio vió que el mundo utópico, místico y espiritual con el que había soñado no existía.

Dotado de una inmensa cultura que no dejó de enriquecer, su atípica educación englobaba, como pilares fundamentales, a Santa Teresa de Ávila, Peter Kropotkin, Fritz Lang o Henry Miller, así como todos y cada uno de los ideólogos en los que se inspira Koyaanisqatsi ${ }^{2}$. La película Los Olvidados (1950) de Luis Buñuel le hizo interesarse por el lenguaje audiovisual. "No era una película amena. Me conmovió profundamente" comentaría más tarde ${ }^{3}$. Nunca antes había tenido contacto con los medios de comunicación audiovisuales, siendo entonces cuando empezó a rumiar una iniciativa de escasos precedentes en el que todo vidente pudiera hacer un peregrinaje a la obviedad. Una obviedad que no tenía por qué ser amena.

Podría resumirse, en líneas generales, que las intenciones creativas de Reggio se basaron en crear un nuevo tipo de cine atrayente en el que los tres protagonistas fundamentales, él mismo, el fotógrafo Ron Fricke y el compositor Philip Glass tuvieran igual importancia; que los espectadores aceptaran un cine no narrativo siempre y cuando no resultara pretencioso y que el mensaje tuviera una riqueza intrínseca de calidad intelectual ${ }^{4}$. Un cine donde se dieran cita la cultura -el mundo y la eternidad- y la vida -el entretenimiento y el placer-.

$\mathrm{Y}$ es que Koyaanisqatsi no cuenta ni con argumento literario ni con actores: se trata de una abstracción. Música, imagen y espectador entran en conflicto trialéctico, desnudándose mutuamente, mientras comparten protagonismo al $33 \%$. El resultado es próximo al del clásico trazado de planteamiento, nudo y desenlace. Sin embargo, aunque el documental posee un guión en ese aspecto, es el público el que

1 BENJAMIN, W.: "La obra de arte en la época de su reproductibilidad técnica", Discursos interrumpidos. Madrid, Taurus, 1973, pág 65

2 Http://www.llhn.com/magu/archives/001259.php.

3 Esta y otras informaciones la hemos extraido del documental "Koyaanisqatsi, The Esence of Life" en DVD "Koyaanisqatsi, Life out of Balance". Metro Goldwyn Mayer, 2002.

4 Ideas básicas perfectamente expuestas y resumidas en: SCHNEIDER, S. J.:1001 películas que hay que ver antes de morir. Barcelona, Grijalbo, 2003, pág 704. 
tiene que buscar toda la riqueza de significados que la obra esconde, puesto que esta tiende a cierta objetividad, mostrando de manera mensurable para el espectador los macro-fenómenos del mundo contemporáneo. Reggio no intentaba sustituir el mundo sensible por una selección de imágenes que estuvieran por encima de éste, ni tampoco hacer una recomposición del medio imitando el cine tradicional, puesto que eso hubiera sido una incoherencia para con su pensamiento, sino presentar -con la irremediable manipulación de la labor de montaje- un viaje, lógicamente estructurado, por el mundo real en el que vivimos.

Volveremos repetidas veces sobre este punto, pero quedémonos con la clave: Koyaanisqatsi es una revisión de la historia de la bella y la bestia ${ }^{5}$ en un mundo en el que ambos elementos son una misma cosa. Esa es, en palabras de Reggio, la contradicción del film.

De hecho, la intención de no dar pistas de ningún tipo y mantener la neutralidad, ejercitando así mejor el criterio del público, llevó a considerar no poner nombre a la obra. Es más, para Reggio nuestra lengua está viviendo un período de humillación y ya no es capaz de describir el mundo que vivimos, por ello, tras algunas deliberaciones oportunas, se decidió usar un término usando la lengua hopi ${ }^{6}$. El curioso nombre, que sin duda confiere al film cierto halo aurático, supuso una vuelta de tuerca más al ya complejo universo de la película, puesto que introducía una serie de profecías de los indios hopi en la banda sonora, con el fin de forzar una explicación del título. Al mismo tiempo, el término Koyaanisqatsi ${ }^{7}$ mantiene la neutralidad, pues de por sí no nos dice absolutamente nada.

\section{Contextualización: El ANTES Y El después.}

Este tipo de cine, en el que las imágenes han de leerse como una partitura es tan antiguo como el séptimo arte $y$, si hacemos caso a Michel Chion, y Koyaanisqatsi la hemos de entender como "película de montaje unanimista ${ }^{8}$ en la tradición de los años $20 " 9$, es precisamente ahí donde deberíamos encontrar las fuen-

\footnotetext{
5 Comentado por el director en el documental "Koyaanisqatsi, The Esence of Life". Véase nota 3.

6 Perteneciente a la rama uto-azteca. La peculiaridad de esta lengua, de la que se ha escrito mucho, es su capacidad de distinguir entre la movilidad de los sucesos puntuales por un lado y la estabilidad relativa de los sucesos permanentes por otro. La variedad de significados de los términos es amplísima. 2000 indios la hablan al norte de Arizona. Uno de los mejores estudios es: WHORF, B.L.: The Hopi Language. 1956 University of Chicago Library.

7 Ko.yaa.nis.qatsi, n. 1. vida loca. 2. vida en tumulto. 3. vida en desintegración. 4. vida desequilibrada. 5. una condición de vida que clama por otra manera de vivir.

8 De unánime: referido a aquél cine en el que música e imagen quedan completamente fusionadas gracias al montaje.

9 CHION, M: La música en el cine. Barcelona, Paidós, 1997, pág 436.
} 
tes de inspiración de este largometraje. Sin embargo, más que en los experimentos de pura abstracción de Viking Eggeling, Hans Richter u Oskar Fischinger, deberíamos fijarnos en una película hoy totalmente olvidada, Manhatta (1921), dirigida por el famoso fotógrafo purista Paul Strand -con la colaboración del no menos importante fotógrafo precisionista Charles Sheeler-.

En ella se deja fluir el bullicio y la vida a través de las calles de Nueva York, desde los muelles donde desembarcan los emigrantes en busca de una nueva vida hasta las fábricas y los barrios obreros. Aunque únicamente dura 6 minutos, la similitud con Koyaanisqatsi, aun cuando solo sea en planos y encuadres, es evidente. Sorprende lo precoz y audaz de la propuesta de Strand, a pesar de que no sepamos la banda sonora que acompañó estas impecables imágenes.

Sea como fuere, debemos retrotraernos hasta Dziga Vertov y su cine-ojo (Kino-glaz) para observar el auténtico comienzo teórico de la tendencia que dio lugar al nacimiento del cine abstracto, puro o íntegro. El fundamento teórico de la objetividad total, de la no narratividad, del protagonismo del montaje y de la relación con la música se encuentra, pues, aquí. Su documental Cinesemana (1918) se convierte así en uno de los ejemplos primigenios, no sólo de esas ideas, sino también de cómo un encuadre o la complejidad del montaje acaban con la ingenua utopía de la objetividad fílmica. El hombre de la cámara (Chelovek s kino-apparatom, 1929), el film que le dio fama internacional, significó el culmen de su poética (Michael Nymann compuso una banda sonora para dicha película, algo que también hizo con Manhatta). A partir de ahí, de Pudovkin a Man Ray, las consecuencias, en un clima cultural inquieto, no se hicieron esperar. A pesar de todo, en comparación con Koyaanisqatsi, todo el cine unanimista de esta década lo podemos considerar, como mucho, de una asepsia crítica de lo proyectado. Más bien se trata de odas triunfales que poco tenían que ver con la dureza de la sentencia de Vladimir Maiakovski: "El arte no debe ser un espejo que refleje el mundo, sino un martillo que lo golpee". Por ello, a nivel de intencionalidad, nuestra película se encontraría más cerca de Tiempos modernos (Modern Times, Charles Chaplin, 1936), aunque el riesgo que asumió Chaplin en ésta se encuentra a casi 50 años de distancia.

Uno de los ejemplos más bellos y acabados del cine unanimista fue la célebre Berlín: Sinfonía de una gran ciudad (Berlin: Die Sinfonie der GroBstadt, Walter Ruttmann, 1927). Es en esta película donde se observa más claramente esa unión música-imagen que tanto nos interesa recalcar: se estructura en movimientos -como si de una sinfonía se tratara- contando, para su realización, con uno de los más versátiles compositores, Edmund Meisel, quién también realizaría una de las bandas sonoras de El Acorazado Potemkin (Bronenosets Potyomkin, Sergei Eisenstein, 1925).Los especialistas coinciden en que su sistema interno de ritmo y montaje la convierten en la película más imitada en dicho campo. Walther Ruttmann afirmaba 
que se trataba de la estructura de una compleja máquina. Una máquina para alabar el maquinismo y el progreso. Justo lo contrario de lo que, en líneas generales, buscaba Reggio.

Tras la II Guerra Mundial esta tendencia fílmica quedó eclipsada. El unívoco progreso científico volvió a eclipsar, una vez más, la ingeniosa creatividad que surge cuando las limitaciones se convierten en un reto: el cine sonoro enmudeció al anterior y los actores del "star system" se convirtieron en reclamo turístico. El cine clásico convirtió en primitivo al europeo.

Tan sólo algunos pequeños documentales de vanguardia, que convivieron en el exilio que las salas de exposiciones les ofrecieron, quedaron como posibles antecedentes americanos del proyecto de Reggio. Se trata de los "videos artísticos" de Stan Brakhage y Hillary Harris. Merecería destacar la labor de esta última en Organism (1975) ${ }^{10}$, por el uso de cámaras rápidas y el frío aliento que exhalaba. Volveremos posteriormente sobre este documental que abrió las puertas a nuevos campos de actuación.

Sea como fuere, si un momento dorado del cine que estamos comentando fue en los años 20, la edad de la chatarra vendría a partir del éxito que, entre los círculos elitistas, tuvo Koyaanisqatsi a partir de su proyección en 1982. La crítica quedó atónita ante tanta perfección, siendo tachada de revolucionaria y novedosa. De la misma manera que Arthur Danto olvidó a Duchamp, los críticos americanos sumieron en una neblina el origen ruso-alemán de esta forma de ver el cine.

La trepidante carrera que tuvo lugar por ver quién conseguía la mayor tajada del pastel, llevó a realizar proyectos donde la base formal -llena de belleza- era la misma, pero la esencia ideológica, sonora o teórica quedaba expoliada. Reggio hizo caso a Philip Glass y planteó una continuación a su primera película, construyendo así una trilogía, que llamó "Qatsi"(vida). Powaqqatsi (1988) siguió las líneas generales de su antecesora, pero éstas se abrian a mensajes maniqueos y difusos que la música de Glass, cercana en este caso al new age, acrecentaba. No es de extrañar: la inversión económica se había multiplicado por dos. Baraka (1992), dirigida por Ron Fricke y rodada en $70 \mathrm{~mm}$ en cinco continentes parecía más bien un conjunto de documentales independientes. El resultado presentaba un aparato crítico paupérrimo, falsas aproximaciones a fenómenos culturales manipulados por el prisma etnocéntrico occidental y "bonitas" imágenes que adolecían de la capacidad de impacto de las de Koyaanisqatsi. La impecable técnica, derrochada en una suma de dinero escandalosa, hacía que estas películas impresionaran al público; nada más.

El entretenimiento de masas había arramblado, una vez más, con la cualidad y calidad cultural. Sólo importaba la eficacia técnica. A partir de entonces los produc-

10 BARNOUW, E.: El documental. Historia y estilo. Barcelona, Gedisa, 1998, pág 270. 
tos de auténtica calidad convivirían ocultos, mientras el resto se hacía de oro. Peter Greenaway o Atom Egoyam usarían las posibilidades de este tipo de cine desde un marco de vanguardia estética en un film de sketches (Shorts, 1998), Claude Nuridsany y Marie Pérennou hacían gala en Microcosmos (1996) de un propósito más lúdico y Reggio en Anima mundi (1992) presentaba, sencillamente, un documental sin palabras. Aunque muchos de estos productos poseían y poseen interés en diversos aspectos, muchísimas obras sin tanta propaganda siguen presentando resultados mejores. ¿Dónde se encuentran? Engrosando almacenes y listas en museos y concursos. En última instancia la esencia de Koyaanisqatsi acabó más bien en los documentales de la Nacional Geographic. Recordemos al respecto que existe un canal por satélite, Landscape, que emite 24 horas al día bellas imágenes acompañadas de música sin narrador.

Desde la comercialidad, un último y loable intento fue de nuevo el de Reggio en Naqoyqatsi (2002). Película que vuelve a presentar novedades estéticas y un riquísimo contenido. Sin embargo, el resultado es tan críptico en el último punto que al final parece una obra estetizante que no intenta decir nada más. A pesar de todo, la reelección de Philip Glass como compositor parecía seguir siendo la más oportuna.

Para concluir este punto nos gustaría subrayar que no se puede enmarcar a Koyaanisqatsi restringiéndola a una línea recta que vaya desde Vertov a Naqoyqatsi. Una cosa es seguir una línea únicamente formalista y estetizante, la que se suele señalar en manuales (y por la que nos hemos decantado finalmente), que sin duda responde en gran parte a los intereses de nuestro objeto de estudio, y otra cosa es el audaz contenido crítico, cuyo origen está en una moderada triple encrucijada de lo expuesto en este apartado, la experimentación turbadora de un Hillary Harris y la ideología del anti-cine situacionista ${ }^{11}$.

No es de extrañar por ello que la parte más sorprendente de Koyaanisqatsi, aquella que presenta Nueva York revolviéndose sobre sí misma a un ritmo frenético en aceleración continua, deba mucho a Organism, mientras que las imágenes de los amenazadores bloques de edificios seriados, la explosión atómica o los agobiantes automóviles parezcan sacadas del "film" La sociedad del espectáculo (La société du spectacle,1973) de Guy Debord, a pesar de que las películas de este último no pretendan ser atractivas por su estética.

En ello se diferencia el anti-cine situacionista radicalmente de Koyaanisqatsi. De hecho, ni siquiera encontramos música de fondo, a excepción de algunos fragmentos de compositores barrocos franceses (F. Couperin, M. Corrette...).

11 Para más información, véase: DEBORD, G.: Complete Cinematic Works: Scripts, Stills, Documents. San Francisco, AK Press, 2003. 


Q articulos José Valentín Serrano García

2. MÚSICA, EGO Y MUNDO ACTUAL.

La música repetitiva, monótona, "machacona" y "latosa" de esta película podría parecer que no merece más de un párrafo. La opinión del espectador una vez vista la película, oscile entre la execración o la admiración, coincidirá en un recuerdo sonoro común: brillantes sonidos sintetizados, voces y reiteración continuada del mismo motivo. Sin embargo, el número real de instrumentos sorprendería a más de uno, de la misma manera que sorprendería la percepción de Koyaanisqatsi si no hubiera sonido o si éste fuera el de obras de Brahms, Vangelis o John Williams. En ese caso, Koyaanisqatsi pasaría a convertirse en un aséptico documental que no llevaría ni la firma de Jacques Ellul, Guy Debord, Ivan Illich o Leopoldo Kohr como inspiradores ideológicos, ni la colaboración incidental del poeta Allen Ginsberg.

La reinterpretación que de la imagen hace la sistemática música minimalista de Philip Glass hace que, por un curioso resultado que intentaremos desvelar, las ideas de estos filósofos, sociólogos y teóricos pueda ser leída por el buen entendedor. Es posible que ni siquiera el montaje y el guión impriman, a pesar de su necesariedad, la fuerza expresiva y crítica que la música le otorga al film.

El montaje y el guión confieren, más bien, un carácter lógico que no entra en colisión con lo expuesto. Se mantiene, en cierto modo, al margen. La fotografía, la otra gran protagonista, le otorga una sensualidad tan pornográfica, que llega a mitigar gran parte de la impactante fuerza sonora y contenidista de Koyaanisqatsi. Es en la contradicción entre la presentación crítica del monstruoso mundo actual y la tecnificada belleza con la que el hombre percibe esta realidad en la que tiene lugar el proyecto de Reggio. De hecho, obviando posturas conservadoras, la propia música de Koyaanisqatsi ha terminado, con el tiempo, convirtiéndose en un elemento de adoración estética. Lo que en principio es un malestar de estómago parece convertirse en el mundo actual en un histérico mar de aplausos. Al final, en el resto de películas fiduciarias de ésta, la belleza ganó la partida. Y la belleza, ciega. Como sostiene Félix de Azúa: "Lo bello ha regresado para dar esplendor a la nada"12.

\section{EL COMPOSITOR Y LA IDONEIDAD.}

La propia infancia y juventud de Philip Glass vienen marcadas por la sorprendente precocidad del mismo. Nacido en Baltimore en 1937, su amor por la música empezó casi al año siguiente, puesto que su padre -dueño de una tienda de músicale traía los discos que no era capaz de vender a fin de observar cuál era la respuesta de su hijo. Con 6 años comienzan sus estudios musicales reglados, recibiendo cla-

12 AZÚA, F.: Diccionario de las Artes. Barcelona, Anagrama, 2002, pág 78. 
ses de violín; dos años más tarde toma también lecciones de flauta y, posteriormente, todavía le queda tiempo y ganas como para especializarse en teclado. Con 19 años se gradúa en la Universidad de Chicago en matemáticas y filosofía ${ }^{13}$, siendo sobre todo esta última la que le marcará sus intereses vitales generales, dará coherencia a sus pretensiones y le hará empezar a replantearse la incipiente y enfermiza visión contemporánea de la música como elemento independiente de la realidad y de la vida.

Su formación musical dio un giro total cuando, con poco más de 20 años, y habiendo recibido clases de compositores como Darius Milhaud o Nadia Boulanger, entra en contacto con la música hindú gracias al influyente papel de Ravi Shankar y, posteriormente, de Alla Rakha. Es en ese momento cuando realizó un viaje a la India con el fin de conocer la filosofía y música de ese lugar sobre el terreno. A partir de ahí emprendió un camino musical totalmente nuevo, influido innegablemente por la coyuntura ideológica, económica y social de la nueva realidad cultural y humana. Esa nueva vía, originada en las artes plásticas ya a finales de los años 50 , la llamamos minimalismo. Corroboramos de este modo la máxima de John Cage: "Todos los músicos experimentales del s. XX han tenido que inspirarse en los pintores"14.

Pero referirnos, en el caso de Glass, únicamente a su faceta compositiva, sería tan erróneo como la consideración actual de la especialización entendida como elementos independientes y fragmentados en los que se sabe todo de nada. La especialización de Philip Glass es la especialización universal de la cultura, aquella donde, por interrelación, se enriquece lo que estaba llamado a ser un compartimento limitado condenado al aislamiento y al absurdo. El perfil artístico y humano de este compositor desborda, para lo que suele ser normal hoy en día, el de una descripción única: director de teatro experimental, escenógrafo, guionista, escritor, intérprete, compositor de todo tipo de repertorio (clásico, operístico, pop, rock, fílmico...) e incluso empresario. A pesar de todo, la riqueza de sus obras se suele basar en la colaboración con otras figuras de relieve, y no tanto en el egocentrismo creativo del que hacen gala tantos artistas hoy en día.

Philip Glass, un autor que despuntó en los años 60 con un producto absolutamente original, pero que cayó, a partir de los 90 , en lo comercial y en la comodidad, podría caer en el olvido -como seguramente pasará con otros compositores minimalistas- si no fuera por su capacidad de crear proyectos en donde él solo es un eslabón más. En sus obras hay, muchas veces, más de Robert Wilson, Jean Cocteau, Samuel Beckett, Yukio Mishima, Mahatma Gandhi, Aphex Twin, Ravi

13 El esquema didáctico de los hitos biográficos más importantes de Philip Glass se encuentra en: ROLDÁN, G.: "Philip Glass", Ritmo, $\mathrm{n}^{\mathrm{a}}$ 770, Madrid, 2004, págs 94-95.

14 KOSTELANETZ, R: Conversing with Cage. Nueva York, Limelight Editions, 1998, pág. 120. 
Shankar, David Bowie, Allen Ginsberg, Jean Genet o Godfrey Reggio que de él mismo ${ }^{15}$. Pero él se convierte en indispensable. Sin él no es posible el resto, lo cuál no es siempre verdad en el caso contrario. Ese es uno de los motivos del triunfo de Koyaanisqatsi.

Si esa estrategia de colaboración y contenidos literarios la ha continuado para así ocultar la pobreza musical que parece mostrar en los últimos años es algo que desborda de nuestro propósito. En un principio de ninguna manera fue así. Lo que sí que debemos preguntarnos es, teniendo en cuenta que nada en la realización Koyaanisqatsi fue fruto del azar o la dejadez, si Glass de verdad era el personaje idóneo para dicho proyecto. Intentaremos a lo largo del artículo responder a dicha pregunta.

El que dicho compositor sea un amante del concepto artístico duchampiano, de las intrincadas teorías de Wittgenstein y ferviente defensor de John Cage, le otorgaba cierta capacidad crítica como para comprender el universo ideológico de Koyaanisqatsi, algo que sin duda era mínimamente necesario. Pero la razón por la que Reggio acudió a él no fue, en principio, el conocimiento biográfico y cultural del mismo, sino la música minimalista. Música que es mímesis del mundo que vivimos. Una proyección de la realidad, cifrada en partituras. No se trata ni de evasión ni de recreación, tampoco de belleza o fealdad -al menos en principio-, sino de una música coyuntural a la realidad social y económica que vivimos.

El fin que la música iba a tener en la película debía ser cercano al readymade y, por lo tanto, las notas debían tener una función similar a la de los planos y secuencias de los altos rascacielos de Manhattan o de los microchips: mostrar el mundo presente. La música debía describir de manera más clara y profunda la imagen, de la misma manera que la imagen orientaría, sin riesgo de anfibología, al propio sonido. El minimalismo subrayaría lo que era importante del fotograma, al margen de lo anecdótico. En 1978, tres años después de haber comenzado los trabajos de filmación, Reggio se reunió por primera vez con Glass. Fue entonces cuando sellaron la siguiente alianza: el compositor realizaría la música por su cuenta y juntos decidirian si le daban más duración a los fragmentos sonoros o si aumentaban las tomas fílmicas. La música tendría entidad propia completamente.

Este proyecto le llegó a Philip Glass cuando se encontraba, seguramente, en la cumbre de su carrera: había llegado al paradigma de su primera etapa -el minimalismo purista-y entraba en uno de los períodos más fecundos de su producción. El cómo encajó este trabajo debe ser analizado desde la naturaleza de la propia banda sonora.

15 Él mismo es totalmente consciente de este hecho. Vid. su punto de vista en GLASS, P.: Music by Philip Glass. New York, Harper \& Row, 1987. Aprovechamos para señalar que no existe bibliografía sobre Philip Glass en castellano: tan sólo manuales generales hablan sobre él. 
Q artículos Aullidos de chatarra. Una aproximación a Koyaanisqatsi...

APUNTES DIVERSOS A PARTIR DE LA ESTRUCTURA MUSICAL.

Desde un punto de vista didáctico Koyaanisqatsi la podríamos dividir en 8 partes atendiendo a las 8 pistas sonoras de Philip Glass ${ }^{16}$. Se nos podría reprochar que, sin embargo, varias divisiones didácticas podrian tener sentido (de hecho, como ya apuntamos, el guión es susceptible de ser reducido a planteamiento, nudo y desenlace).

Eso es rigurosamente cierto, pero aquí lo que más nos interesa es recalcar la función organizadora que la música realiza y, de hecho, la percepción del espectador comprende Koyaanisqatsi como un grupo de secuencias relacionadas, que empiezan y acaban con una nueva pista de sonido.

La música otorga, en todo momento, una estructura ${ }^{17}$ interna al film. De hecho, hemos de distinguir la música del "planteamiento", cuya función es estructural, incidental e introductoria, de la del "nudo-desenlace", donde las notas se convierten en protagonistas. Aunque con morfología desigual, Koyaanisqatsi se mantendría bastante intacta si las primeras secuencias contaran con otro tipo de música.

Prólogo: 4' aprox.- Koyaanisqatsi- Se trata de una obertura. Usando un órgano y un bajo vocal, en una atmósfera sagrada y ritual, unas extravagantes imágenes que, a priori parecen no tener significado, se suceden con excesiva lentitud. El significado del que queda impregnado el ambiente acústico guarda relación con las pinturas rupestres prehistóricas que en escena aparecen. Las preguntas ¿Quiénes somos? ¿De dónde venimos? Y ¿A dónde vamos? Cobran vida mientras la música tiende un velo de misterio sobre ellas. Esta obertura pretende ser una arqueología de la conciencia.

1.- Planteamiento: 13 ' aprox.

Organic.- Tomas aéreas sumamente estáticas de bellos y desérticos paisajes naturales son acompañadas por el sonido manipulado de suaves crescendos de cuerdas [1]. Un instrumento de viento rompe esa suavidad, introduciendo un impertinente motivo que se irá desarrollando cada vez más y que antecederá el motivo rítmico más repetido en la totalidad del film: el arpegio ${ }^{18}$.

16 Existe algún que otro pequeño fragmento del film cuya música es de Michael Hoenig, uno de los guionistas de Koyaanisqatsi. No prestaremos, empero, atención a esos fragmentos. Se trata de una música que toma lo esencial de la música de Philip Glass, con una función bisagra en la mayor parte de los casos.

17 PASCUAL, J.: Guía universal de la música clásica. Barcelona, Ma non troppo, 2004, pág. 147: "P. Glass considera que existe el sonido porque existe algún tipo de estructura (...) basándose ésta en la mera repetición". La música minimalista cumple funciones organizativas porque es, de por sí, una férrea estructura cuyo pilar básico es la repetición. (....) "La repetición, a veces obsesiva, y el uso de poco material tienen mucho de oriental". Forma repetitiva y alma oriental definen, de hecho, la música de Glass. 


Q: artículos José Valentín Serrano Garcia

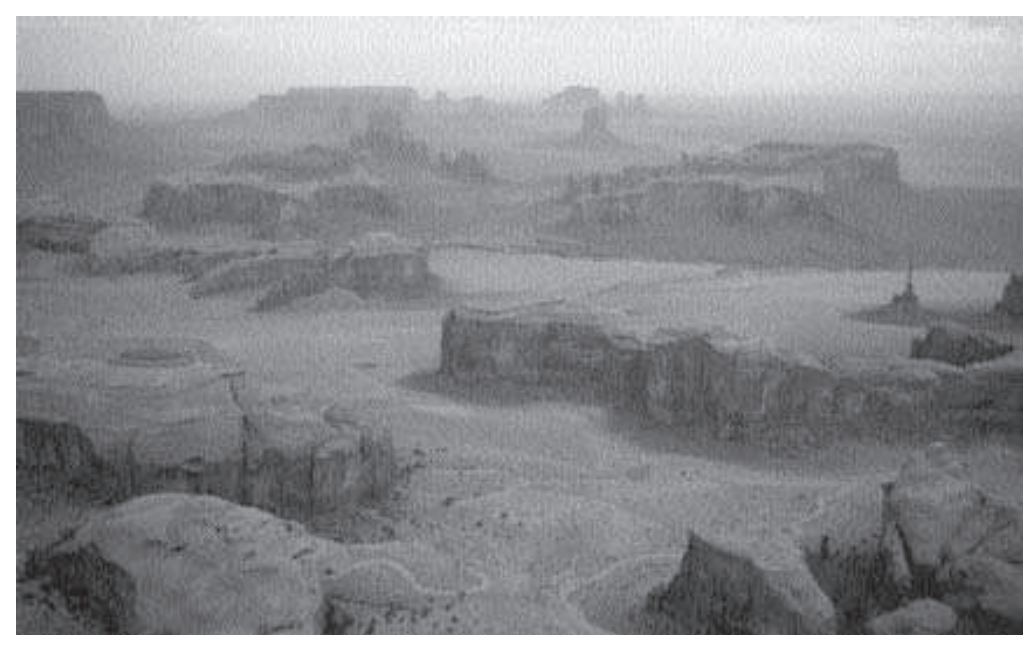

1. Tomas aéreas de desolados paisajes desérticos en los primeros minutos de Koyaanisqatsi.

Cloudscape.- De los planos generales anteriores pasamos a tomas más cercanas y, por lo tanto, el movimiento interno de la imagen, aún lento, toma más ritmo. Ese efecto será reforzado por la música: al final es la percepción por parte del espectador, gracias al fenómeno audiovisual, la que sustituye la realidad. El viento metal (en un principio, trompetas con sordina) nos divide el tiempo con más presteza a base de módulos rítmicos que se repiten continuamente, mientras la cámara llega a realizar sutiles balanceos.

El tiempo que marca el transcurso de la película empieza a quedar atrapado en la retícula en tic-tac entretejida por el minimalismo. La sentencia de Tarkovski "el

18 A partir de un acorde -base armónica consistente en varias notas tocadas simultáneamente-, el arpegio
consiste en tocar sucesivamente, en su forma más básica, dichas notas siguiendo una progresión ascenden-
te o descendente -en cuyo caso se podrían mantener hasta el infinito, al tratarse de una progresión aritméti-
ca simple-. Philip Glass hace del arpegio su "leit motiv" musical, repitiéndolo por doquier de manera constan-
te. Para otorgarle una función rítmica más precisa, lo suele introducir en tresillos -caso de Vessels, por ejem-
plo-, imprimiéndole un efecto particular y artificioso. A diferencia de una escala, también sumamente simple,
en la que las diferencias entre unas notas y otras le otorgan un carácter más rico y variado, el arpegio se con-
vierte en un paradigma del módulo básico sistemático-adicional, obligado a mantenerse en una misma línea
y acorde ad infinitum. El efecto hipnótico del acorde es, por tanto, difícilmente superado por cualquier otro
módulo que posea tres notas diferentes. El arpegio en ostinato es la clave de la mayor parte de la producción
de este compositor. 
cine es el arte de esculpir el tiempo"19 es insuficiente puesto que de por sí, el minimalismo, al dividir el espacio-tiempo en instantes independientes e individuales, ejerce una despótica tiranía frente a cualquier intento de tiempo orgánico (lo que Henry Bergson llamaba "duración auténtica"), entendido éste como fragmentos desiguales que se acumulan en la experiencia humana. El minimalismo divide, por medio de instantes objetivos, el tiempo y el espacio visual a su antojo de una manera parecida al funcionamiento de un reloj. Produce sin pausa un espacio y tiempo isomorfo susceptible de predecir. Tal vez por ello nos da esa sensación de artificialidad20: en el hombre y naturaleza el tiempo es aleatorio e impredecible hasta cierto punto.

Resource (Sólo el principio).- Los ritmos musicales, a base de arpegios y módulos repetitivos, contenidos anteriormente por la lentitud de la imagen y por la densidad de otros instrumentos, llegan a un repentino clímax. La aparición del sintetizador, apoyado por un clarinete bajo (seguramente), marca un importante punto de inflexión. En realidad, aunque el movimiento se acelera, la temática sigue estando próxima al planteamiento, mas la música ya nos está introduciendo en el mundo propio de Koyaanisqatsi. Hasta ahora la música solo había tenido una función incidental y prefiguradora del sonido que realmente importa: el que aparece a partir de este momento.

\section{2.- Nudo: 20' aprox.}

Resource.- Llegado un momento, la imagen cambia. Ya no se trata de la naturaleza, sino de la aparición de la técnica en aquella [2]. Las cuerdas e instrumentos de viento -sean de manera o metal- forman un microclima en crescendo continuo, basado como siempre en la repetición de motivos [3], con una tendencia clara al dramatismo que desembocará de nuevo en el dominio absoluto del sintetizador. De hecho, la cadencia fílmica adquiere fuerza tan solo por efecto del sonido.

A partir de este preciso instante el suspense será una de las características definitorias del efecto psicológico de la música sobre el espectador. Una música que va creando tal exceso de información suspendida durante tanto tiempo obliga a una resolución que ha de llegar tarde o temprano. Philip Glass resolverá generalmente por aceleraciones del ritmo y paroxismos repetitivos que se orientan al infinito.

El suspense se refuerza por la relación absoluta entre música e imagen, gracias a una sincronización ${ }^{21}$ unidireccional, continua y frenética. Esta característica,

\footnotetext{
19 De hecho, es el título de su libro. TARKOVSKI, A.: Esculpir en el tiempo, Madrid, Rialp, 1999.

20 En CHION, M.: El sonido. Barcelona, Paidós, 1999, pág 35; el autor dice, asimismo, que este tipo de música "evoca una temporalidad arcaica", puesto que relaciona -adentrándose en fenómenos perceptivoslos ciclos pendulares de las palpitaciones cardíacas que todos nosotros, siendo fetos, hemos escuchado, con la música minimalista de repetición.
} 


2: artículos José Valentín Serrano Garcia

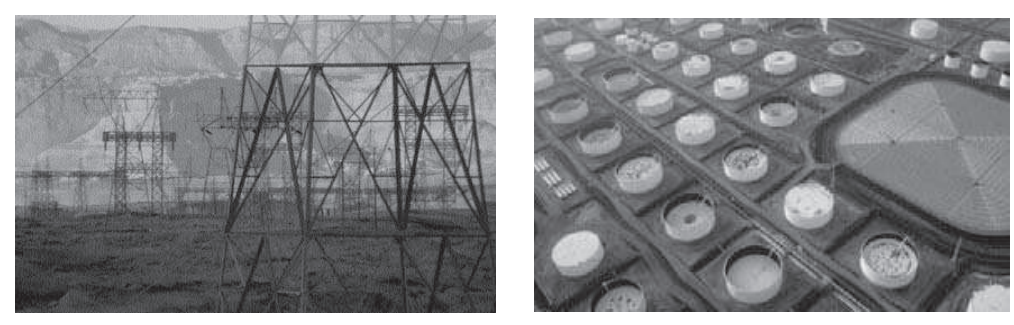

2. El sonido describe la impresión visual, metálica y aristada, que producen las torres de alta tensión en contraste con la naturaleza.

3. Los paisajes industrializados, irritantemente fríos y homogéneos, fuerzan la aparición de una música repetitiva.

debido a la puntuación constante que los módulos isorrítmicos marcan, obligan a encontrar elementos visuales que, por repetición, parezcan moverse o seguir la regla geometrizante de dichos módulos. [4] De este modo, cualquier elemento geométrico que se repita en la imagen (ej: edificios constituido por ventanas idénticas, elementos pulidos, centenares de carros de combate alineados...) o que se mueva uniformemente siguiendo el ritmo musical (ej: escaleras mecánicas, cadenas de producción, interminables líneas de coches circulando por carreteras...) toma fuerza propia y queda destacado, al mismo tiempo que define su esencia al tomarla prestada de la propia música.

Vessels [5]: Haciendo gala de una estructura tripartita (A, A' y A"), cada vez más acelerada, extática y dinámica, Vessels introduce, por vez primera, las voces: el segundo punto de inflexión en la banda sonora. La lectura erótica que a veces se ha querido ver en la obra de Philip Glass puede parecer a priori extravagante, pero a posteriori resulta interesante si meditamos sobre la labor de las voces en esta partitura: gemidos sexuales que piden más intensidad con una voracidad y constancia tal que originan terror. Una nueva visión de la tensión eros - thanatos.

Una de las intenciones de la película es que parezca que la banda sonora está prácticamente construida con sintetizador y voces. No es de extrañar. Aunque en verdad la profusión de instrumentos es generalmente bastante grande, la propia manipulación sonora a la que han sido sometidos hace que se encuentren al antojo

21 Para más información, consúltese: CHION, M.: La audiovisión. Introducción a un análisis conjunto de la imagen y el sonido. Barcelona, Paidós, 1998, págs. 61- 62. "Un punto de sincronización es un momento relevante de encuentro síncrono entre un instante sonoro y un instante visual". 

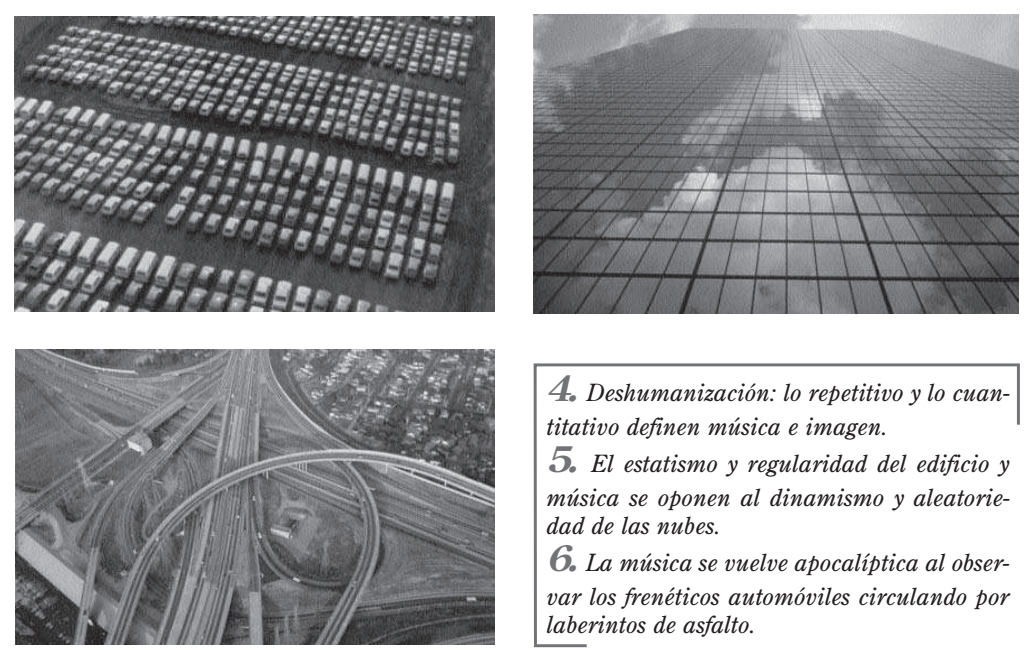

4. Deshumanización: lo repetitivo y lo cuantitativo definen música e imagen.

5. El estatismo y regularidad del edificio y música se oponen al dinamismo y aleatoriedad de las nubes.

6. La música se vuelve apocalíptica al observar los frenéticos automóviles circulando por laberintos de asfalto.

y servicio de la artificialidad y de la homogeneidad, esto es, del sintetizador22.

A partir de Vessels, y hasta Prophecies, la música presenta una tensión continua, una dinámica violencia susceptible de estallar, una aceleración continua, un autoconsumo ahogado en su repetición invariable, un clímax eterno y un trance hipnótico. A veces, la música lleva al orgasmo al tecnócrata, otras, a poner carne de gallina al tecnófobo. El aullido de las voces exige una respuesta al espectador de la misma manera que el Aullido de Allen Ginsberg pedía una revolución [6].

¿Qué presentan, entretanto, las imágenes a partir de aquí? ¿Cómo son los planos o movimientos de cámara? Presentan lo que la música proyecta y la cámara queda bajo el yugo de la batuta de Philip Glass. El diálogo entre imagen, cámara y sonido es polidireccional: desde travellings, balanceos, primeros planos, panorámi-

22 Aclaración fundamental: Usaremos el término sintetizador con fin didáctico. Cuando utilicemos dicho término nos referiremos tanto a los keyboards bajo el control del único instrumentista encargado de ellos (Michael Riesman) como a la percepción que de gran parte del sonido advierte el espectador como sintetizado. La profesionalidad de los instrumentistas especializados en la música de Philip Glass así como la manipulación sonora a la que son sometidos flautas y saxofones consiguen un resultado idéntico (o "casi", para el experto) al del sonido de un sintetizador en momentos en los que puede que éste ni exista. No es de extrañar: Philip Glass estuvo trabajando con sintetizadores durante más de 20 años, razón suficiente para que en nar. Philip Glass estuvo trabajando con sintetizadores durante más de 20 años, razón suficiente para que en Koyaanisqatsi intente, con la ayuda de otros instrumentos, conseguir el mismo resultado artificioso o, en todo caso, que los instrumentos de viento encargados de doblar la línea melódica del keyboard enriquezcan el sonido de éste sin que el espectador note, en la práctica, su presencia. De este modo nos decantamos por deno-
minar "sintetizador" a aquello que el espectador perciba como tal. Si no nos tomáramos esta licencia didáctica habría que entrar en numerosas especificaciones que no nos interesan para nuestro propósito. 
cas, tomas aéreas...en principio, en crescendo dramático, después, de cualquier modo.

Pruit lgoe: Poco más hay que decir a lo expuesto en el punto anterior. Aunque en principio la calma se apodera de las estáticas imágenes, y podemos mensurar claramente el sonido de las cuerdas por última vez, pronto aparecerá el sintetizador y con él, las voces. El uso de instrumentos de viento metal, cuerdas o viento madera, aunque fundamentales, es bastante tópico. Tópica en recursos -si los observamos individualmente y no en conjunto- y carente de innovación armónica o rítmica es, de por sí, la mayor parte de la música de Glass.

De hecho, el interés de toda la música de esta banda sonora no puede ser calibrado desde un punto de vista meramente técnico o formal, sino desde el significado que la propia forma artística lleva impreso.

"Desenlace 1": Aunque podríamos llegar a la conclusión de que éste se encuentra más cercano al Nudo -de hecho, formalmente es deudor en todos los aspectos de la impactante fuerza de las secuencias anteriores-, la importancia mayúscula de esta secuencia, por duración, protagonismo y temática, hacen que Vessels y Pruit Igoe parezcan antesalas preparatorias desde un punto de vista organizativo, nunca jerárquico.

The Grid (22'): La gran secuencia de The Grid, de más de 21 minutos de duración, constituye el núcleo duro de Koyaanisqatsi. La ciudad de Nueva York desde diversos puntos de vista, de día o de noche, se convierte en un gigantesco decorado definido y descrito por cámaras rápidas, rapidísimas, y por el record de seriación mantenida de los mismos motivos sonoros. La macroestructura de las megalópolis actuales queda al desnudo. Aunque esa idea ya hubiera sido introducida musical y visualmente en las dos secuencias anteriores, alcanza aquí un tope tal como para poder considerarla una entidad en sí misma. El ritmo de planos se vuelve muy rápido y la cadencia fílmica, entre tanto, por efecto de la cámara rápida y de la aceleración que la música sigue imprimiendo a la imagen, llega a momentos en los que parece alcanzar el límite de lo posible. La riqueza sonora de los sintetizadores es apoyada por saxofones, flautas y demás instrumentos.

Llama la atención poderosamente que la categoría estética musical de esta secuencia se encuentre más cercana a lo cómico que a lo trágico: el sarcasmo, lúdico e irónico, se convierte en el contrapunto ideal al resto de secuencias. A pesar de todo, Glass suele dar un tono dramático a sus obras. Por algo será.

Merece destacarse que, aunque hablemos continuamente de la repetición infatigable y homogénea de Philip Glass, ello es verdad únicamente en el recuerdo que nos queda de ella. La influencia de la polirritmia hindú es observable en la con- 
tinua oscilación entre ritmos terciarios y binarios de cada línea melódica, así como en los pequeños y sutiles cambios necesarios para no hacer que el efecto sea inaudible 23 . La repetición constante no existe ni en notas ni en ritmo: no tendría sentido alguno y nadie podría soportarla -al menos, por ahora-. Ahí está el trabajo como profesional de nuestro compositor.

\section{"Desenlace 2":}

Prophecies (14'): La música nos otorga un merecido descanso. Únicamente el sonido de un órgano -un órgano que parecería sintetizado, como se desprende de la excesiva frialdad del mismo- y un coro que enuncia, a modo de lamento contenido, tres profecías hopi. El cansancio se apodera del espectador: un ritmo lento, planos de conjunto o medios y, sobre todo, el contraste que la música ocasiona, después de más de media hora de tensión acumulada, inducen a un sueño lleno de pesadillas.

Este fragmento nos evoca algún tipo de música sacra, sobre todo el canto gregoriano. La música conlleva, pues, un espíritu penitente de profundo sentido religioso para el público occidental, así como cierto hálito redentor. Sin embargo, las profecías, de cuyo significado nos enteraremos más tarde, no tienen el poder de reconfortarnos: el panteísmo que rezuman no tiene ya cabida en una sociedad materialista.

La música desempeña en Prophecies, a pesar de todo, un papel más incidental para el espectador medio. El final este fragmento repite la obertura Koyaanisqatsi. El círculo se ha completado, argumental y musicalmente.

\section{LA DEUDA DE KOYAANISQATSI.}

Philip Glass es un compositor que recicla, cita y repite continuamente las mismas fórmulas en obras cercanas en el tiempo. Suele parecer que se trata de la misma obra, pero el mínimo cambio, aunque no lo parezca a priori, es fundamental en un estilo tan sumamente uniforme.

El único trabajo de envergadura que Philip Glass había tenido en un medio audiovisual con anterioridad a Koyaanisqatsi fue el de realizar la banda sonora del documental Mark Di Suvero, sculptor (1976) de Francois de Menil. Los orígenes de Koyaanisqatsi en el uso de diversos timbres en el sintetizador ${ }^{24}$ y en el empleo de las voces están tanto aquí como en su obra más importante, la ópera Einstein on the

23 Se ha utilizado para este tema y otros puntuales relacionados con el estilo y medios de Philip Glass PALISCA, C. V. y GROUT, D. J.: Historia de la música occidental, vol. 2. Madrid, Alianza, 2004.

24 Vid, supra. Nota 14. 
Beach (1977), si bien en nuestro motivo de estudio prescindió del violín solista; en la célebre Music in twelve parts (1976)- considerado el "Arte de la fuga minimalista"donde quedaban claros sus principios de adición infinita, y en Another look at Harmony, Part 4 (1975). En esta última, una pieza de 50 minutos de duración, el "ensemble" coral consigue sensaciones y efectos misteriosos, intimistas, dinámicos y religiosos en una metamorfosis continua. "Vessels" o "The Grid" deben mucho a ese uso de las voces.

Por otra parte, los arpegios suspendidos durante decenas de minutos, manteniendo el suspense y la atmósfera dramática, provienen de varios proyectos que se estaban realizando o rumiando a la par de Koyaanisqatsi: las óperas The Civil Wars, Satyagraha o Ahkenatón -baste oír el preludio de esta última- son elocuentes en varios de sus pasajes.

\section{ORIGEN Y ESENCIA MINIMALISTA EN KOYAANISQATSI.}

Sin embargo, la descripción técnica, formal y estructural de la música en relación con los segmentos fílmicos no nos soluciona prácticamente nada. La partitura de Glass no presenta tampoco, a la vista de los resultados de un análisis técnico, interés. Como mucho podemos llegar a la conclusión de que a veces hay una tendencia a lo trágico, pero siempre basado en progresiones armónicas muy típicas, en clichés. Es tan simple que llega a parecer una coacción a la libertad e imaginación. La mente y el oído no pueden sorprenderse por casi nada, toda la concentración queda en lo hipnótico y en lo rítmico.

¿Cómo es posible que una música tan austera, fría y dictatorialmente repetitiva se haga con el espectador? Comprender la música minimalista depende, en gran medida, de haber entendido el origen lejano de la misma, así como comprender el cambio interno que ha sufrido el hombre en su concepto de escuchar música. En este sentido, dado que, en palabras de Godfrey Reggio, Koyaanisqatsi "trata de que todo en el mundo: religión, cultura, educación (...) es técnica", es precisamente ahí donde debemos encontrar la raíz.

Desde la destrucción del ritmo oratorio por culpa de la aparición del reloj, momento en que tiene sentido la aparición de los compases y de los tiempos musicales, la sistematización y determinación de la música occidental, por unos u otros motivos, no ha conocido límites. En ello poco ha tenido que ver la evolución -que no progreso- de la música misma, sino más bien de los elementos culturales y técnicos externos a ella. Si la música en momentos primitivos mostró una determinación más humana, el paso del tic-tac del reloj tuvo, en última instancia, la palabra definitiva ${ }^{25}$.

25 MUMFORD, L.: Técnica y Civilización. Madrid, Alianza, 2002, págs 32-33. Varias de las ideas y concep- 


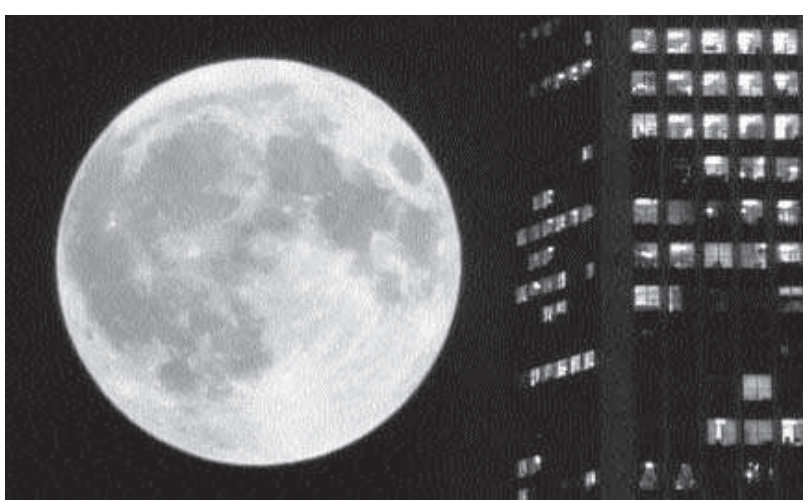

7. Las formas geométricas perfectas de la luna, rascacielos y ventanas quedan delimitadas por la propia música.

No es de extrañar por ello, que en Koyaanisqatsi, la música actúe de irritante metrónomo.

La matematización de las estructuras sonoras encontró un punto álgido en el mundo protestante de los siglos XVI al XVIII. No es de extrañar; el concepto de que sólo una vida ordenada sometida a leyes científicas inmutables (otorgadas por la divinidad) podía alcanzar el Paraíso, pesó sobremanera en compositores de la talla de J.S. Bach: su música, de este modo, presentaba en código cifrado $-y$ con un resultado didáctico envidiable- el desideratum del hombre como máquina sometida a reglas férreas.

Todo esto explica en gran parte un devenir histórico que alcanzó el apogeo con el minimalismo. No es de extrañar que Reggio comentara en cierta ocasión: "Dejo el contorno matemático para Philip Glass" [7]. Philip Glass en su aspecto más simple y el serialismo integral en el más complejo son el ejemplo de unas tendencias musicales determinadas por la divinidad de las matemáticas.

Pero el cambio más profundo, y ahí entra el mundo de Koyaanisqatsi en escena, fue en el momento en que el rápido golpe en stacatto de las máquinas industriales decimonónicas desplazó los improvisados ritmos de los cantos en los talleres medievales. La saloma de los marinos al tirar de los cabos, las variaciones

tos que vamos a esgrimir como definitorias de la evolución de la música para el propósito que nos interesa encuentran una explicación más amplia y completa en este estudio clásico. 
musicales creadas por los campesinos, el párroco del pueblo tocando el órgano en una fiesta local o la capacidad de invención musical popular que tan buenos resultados dio cuando se fundió con la música "oficial" (fandangos, folias, bourrees, zarabandas...), morían lentamente. La vida durante los siglos XIX y XX se fue orquestando progresivamente por el número de revoluciones por minuto, más bien que por el ritmo del canto, la salmodia o el tamborilero. La repetición fría y áspera empezó a dividir el tiempo de trabajo y se clavó en las conciencias humanas. La música de Koyaanisqatsi parece, de este modo, la aceptación absoluta de ese cambio y la mímesis acrítica de sus consecuencias.

La balada, dice Mumford, "con sus antiguos contenidos religiosos, militares o trágicos, se disolvió en la canción popular sentimental, envuelta incluso en su erotismo: el patetismo se hizo sensiblería". En otro párrafo, el cuadro queda completado mucho mejor: "La música y la poesía dejaron de ser patrimonio del pueblo: se han hecho literarias, profesionalizadas y segregadas" 26 . Un elitismo, tan al margen de la experiencia y necesidad humana, que llegó a crear el minimalismo: la artificiosidad extrema, defendida por el "progreso" especializado.

La esencia del sonido mismo también fue retocada en el mundo occidental. La orquesta barroca edificada sobre el volumen de instrumentos muy distintos entre sí, la aleatoriedad del matiz sonoro impreso por una cuerda hecha de material orgánico, los distintos tipos de afinación no sometidos a una orden irrevocable o la diferencia irreconciliable entre una consort de violas da gamba y un grupo de violas da braquio daban voz musical a las características humanas de diferencia, aleatoriedad o indeterminación absoluta. La antítesis de Koyaanisqatsi.

Sin embargo, la invención mecánica por un lado, y las normas culturales por otro, cambiaron aquel sistema. La producción del sonido se fue calibrando científicamente: el timbre o el tono se hicieron, pues, dentro de ciertos límites, estandarizados y susceptibles de predecir. El control absoluto de la "objetividad27" sobre el instrumento y el sonido dieron prioridad a la unívoca homoneidad frente a la heterogeneidad de propuestas existentes. Algo parecido pasó con la morfología de diversas familias de instrumentos musicales: en el Renacimiento las formas eran irregulares y diversas; en el Barroco, sutilmente diferenciadas con ornatos, colores y detalles antropomorfos; el Clasicismo y Romanticismo las fue convirtiendo en anónimas, y el siglo XX originó la mesa de mezclas y el formato MP3. En paralelo, la colonización y la globalización arrasaron con cualquier sistema sonoro en el que las "convenciones" no fueran las occidentales. Lo que pasó con el sonido se proyectó en nuestra reali-

26 íbidem, pág 224.

27 Para más información sobre la búsqueda en el siglo XX de la objetividad radical en contra de lo subjetivo o evocativo, véase el capítulo sobre música en: RUBERT DE VENTÓS, X.: El arte ensimismado. Barcelona, Anagrama, 1997. 
2: artículos Aullidos de chatarra. Una aproximación a Koyaanisqatsi...

dad circundante tal cual. Quizás por ello la relación entre imagen y música en Koyaanisqatsi es absolutamente indisoluble.

La propia definición de la orquesta, como entidad sobresaliente, se hacía eco social de toda aquella metamorfosis: el intérprete se medía por la extensión con que servía al proyecto musical, pero la obra no se medía por la extensión con que servía a éste. El desinterés kantiano se mostraba demasiado desinteresado. En el film, de manera semejante, el hombre parece no ser dueño de su propia vida: sólo es valorado por la extensión con la que sirve al mito del progreso.

Entiéndase ahora la llegada y aceptación del sintetizador como cúspide de este proceso de estandarización formal y sonora, así como el futuro que nos aguarda: obras musicales enteras se han realizado con sintetizadores experimentales $\sin$ que expertos en audición apenas puedan encontrar diferencias. El sonido queda aprisionado. Es normal, el uso de las cuerdas del que Philip Glass hace gala en Koyaanisqatsi se basa en la maquinización del intérprete y del resultado sonoro. La ausencia de acentos, glisandos, rubatos, vibratos, oscilaciones, ect.; la nota concreta y estática del sintetizador o las voces encarceladas entre dos o tres notas, sin posibilidad de inflexión, nos educan en una percepción que empobrece nuestro oído sin que seamos conscientes de este hecho. Al final, el paradigma de la música electrónica -hoy por hoy introducida en todos los sitios: desde los videojuegos a la música pop-, se hace bella por una sencilla razón: "Lo que generalmente llamamos bello no es sino una sublimación de las realidades de la vida28" A ello añadiríamos: "porque no hay otra salida". El problema es cuando nos destruye la capacidad autocrítica. No es de extrañar, por otra parte, que Philip Glass esté considerado el abuelo de gran parte de las tendencias trance.

El propio "Glass ensemble" que toma parte en la interpretación de Koyaanisqatsi se mueve entre parámetros que llevan al hastío. Baste ver la diferencia entre un buen instrumentista en la actualidad y en la época barroca. En el presente la diferencia la marca, en la música clásica, ante todo, la expresividad en el fraseo y la técnica, mientras que en el barroco es la capacidad de improvisación, de libertad, de reinterpretación de la partitura, de realización creativa... En el primer caso se trata solo de ejecutar la cultura ${ }^{29}$, en el segundo, de realizarla en la vida. Algo parecido pasa con el espectador. No es de extrañar, por ello, que tantas generaciones se decantaran por el jazz o el rock como medio de huir de esa "muerte de los sentidos", algo que es evidente si pensamos en los intérpretes de Koyaanisqatsi.

¿Qué es, en esencia, la música de Koyaanisqatsi al fin y al cabo? Una técnica [8].

28 TANIZAKI, J: El elogio de la sombra. Barcelona, Siruela, 2005, pág. 44.

29 Véase, para más información sobre la devaluación del intérprete a partir del romanticismo, COOK, N: De Madonna al canto gregoriano. Madrid, Alianza, 2005. págs. 42, 54 y 104. 


- artículos José Valentín Serrano García

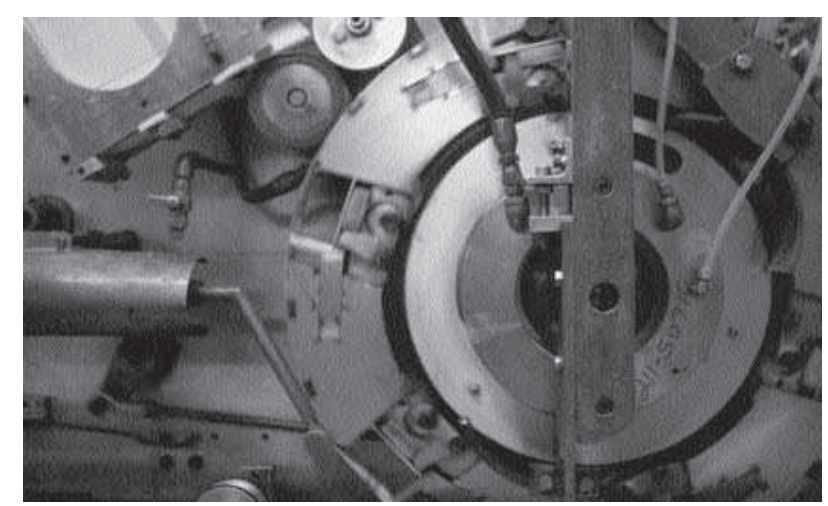

8. Maquinismo y técnica en Koyaanisqatsi.

"La música se ha transformado gracias al efecto de las técnicas que no son en principio técnicas musicales (ni metodología musical, ni construcción de instrumentos): (...) la música electrónica (...), que reposa en el uso de útiles técnicos a priori no musicales. En estas músicas ya no hay ejecutante y las estructuras musicales ancestrales de la música son pulverizadas, desintegradas. (...) Un predominio de la estructura y el ritmo, que corresponden totalmente al ambiente técnico"30

La comprensión de esta partitura minimalista sólo es posible asimilando, en su justa violencia, este apartado. Los autores que ahora vamos a estudiar presentan, de hecho, una visión crítica del devenir histórico en la vía de lo que acabamos de comentar. Advertimos de nuevo que la música de Philip Glass resultaba necesaria para retratar el presente: la lógica histórica demuestra que no hay nada de gratuito en la aparición de esta poética sonora.

El contenido de Koyaanisqatsi, por su parte, parece explicado en los accidentados pasos que la música "oficial" dio en el pasado y también en sus consecuencias actuales. 30 ELLUL, J.: La edad de la técnica. Barcelona, Octaedro, 2003, pág. 134. Jacques Ellul está considerado
uno de los grandes filósofos en las relaciones entre tecnología y sociedad. 


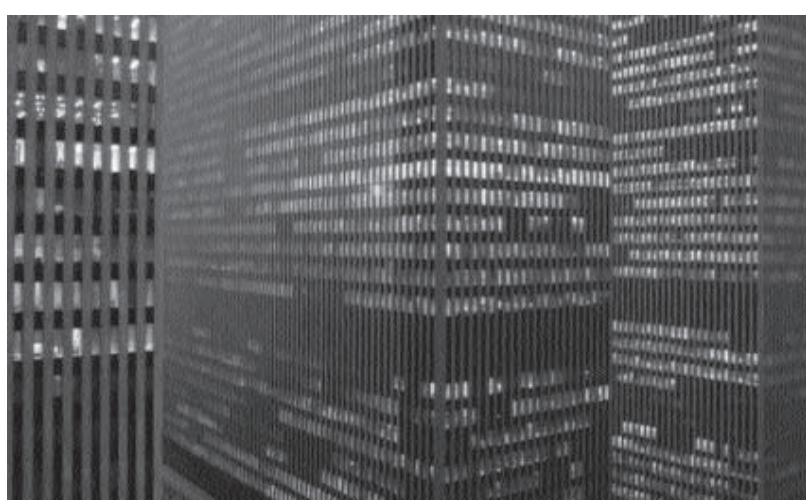

\footnotetext{
9. La seriación y reticularización de nuestra propia realidad circundante se proyecta en la música minimalista.
}

BREVES PINCELADAS SOBRE EL DIALOgo ENTRE IDEOLOGIA Y MÚSICA.

Uno de los fenómenos más curiosos de Koyaanisqatsi -algo ya comentado en varias ocasiones- es, precisamente, la idoneidad de la música en relación ya no con la propia concepción del film, sino con la finalidad ideológica y crítica.

Los ideólogos de Koyaanisqatsi, sobre todo los más importantes por la universalidad de sus comentarios (Ivan Illich, Guy Debord y Jacques Ellul), no suelen presentar alternativas en su mayoría. Solo muestran críticamente una realidad. La solución la dejan en manos del público. El mismo paralelismo encontramos en la música de Philip Glass: no se trata de proponer un proyecto, como sería la Sinfonía del Nuevo Mundo de Dvorak o la novena de Beethoven.

La música minimalista presenta una serie de características básicas de excesiva racionalidad y artificialidad que, curiosamente, son los caracteres que J. Ellul considera definitorios de la nueva relación entre técnica-sociedad-individuo (base temática de Koyaanisqatsi). Ellul expone que todo proceso técnico actual presenta una excesiva racionalidad, creando una estandarización del pensamiento y "excluyendo la espontaneidad y la creación personal (...) reduciendo todo al esquema lógico de los hechos, de las pulsiones, de los fenómenos, los medios y los instrumentos"31 [9]. Eso es la música de Glass. Tampoco podemos olvidar al respecto la

31 Op. Cit, pág 85 
influencia del concepto de desindividualización creativa oriental en nuestro compositor. Como militante budista, e influido por el propio mecanismo de la música hindú, lo personal queda al margen de la construcción artística.

El segundo carácter, para Jacques Ellul, es la artificialidad: "la técnica como arte es creadora de un sistema artificial (...) Es un mundo artificial que destruye, elimina o subordina este mundo natural, pero no le permite ni reconstruirse ni estar en simbiosis con él"32. Esta idea aparece en las imponentes imágenes en las que el público observa un universo lunar compuesto de cemento, asfalto, fundición, cristal o acero; sometido y recluido por los reglamentos y las necesidades arquitectónicas que desembocan en el mundo anónimo de callejones, encontrando en el sintetizador y la contención sonora su punto crítico.

Desaparece la influencia de la "música natural": los sonidos aleatorios y disonantes de la naturaleza o de las inflexiones humanas desaparecen. Se trata de artificialidad. La palabra pintor en griego se decía zographos (el que escribe lo que está vivo). Aquí podemos hablar, con toda legitimidad, de un artifex. Philip Glass compone para lo que está muerto en un acto de sinceridad y honestidad hacia el mundo que le rodea. Baste recordar las imágenes en primeros planos de los automóviles en "Vessels", continuados por tomas aéreas de autovías y autopistas, así como el brillo metálico de coches y camiones justo en el momento en el que, tras las voces, aparece el sintetizador acelerando el ritmo sin piedad, haciéndose eco de esos artificiales colores de las lacas del automóvil. Si echamos marcha atrás y observamos los colores de la naturaleza controlada por el hombre (en "Resource"), veremos algo semejante. El sintetizador se encuentra en ambos lugares repitiendo las mismas notas con el mismo timbre.

La banda sonora de Koyaanisqatsi parece actuar por sí sola. Tan pronto como se le da una primera orientación, unos primeros compases, el resto parece hacerse por derivación única. De la misma manera, Organism presentaba la ciudad de Nueva York creciendo a ritmo vertiginoso ineludible, respondiendo a una necesidad inhumana. Las cámaras rápidas de The Grid tienen la misma función. La aceleración imparable y estresante no es controlada por el hombre. En ese sentido, apliquemos la frase de Ellul "the one best way: el automatismo es el resultado de que la orientación y la elección técnica se efectúan por sí solas ${ }^{33}$ ". Idea parecida se encuentra en Debord: cualquier mejora del método será en un único camino imparable. Otros capítulos del libro La edad de la técnica resultan elocuentes solo por su título: autocrecimiento, universalismo, autonomía..., aplíquense esas características a las notas de Philip Glass o a la propia película en sí.

32 Ibídem., pág. 85.

33 Ibídem., pág. 90 . 
2: artículos Aullidos de chatarra. Una aproximación a Koyaanisqatsi...

La macroestructura musical diseñada por Philip Glass tiene también mucho de Iván Illich, una de las figuras más admiradas por Reggio. La crítica de este autor a las inalcanzables, crípticas e intrincadas instituciones ${ }^{34}$ tiene mucho de desesperanza: el hombre se encuentra reducido a cosas. La música de Glass, con su intrínseco anonimato, no puede definir al hombre, solo a cosas. "El ser humano parece un consumidor que recibe y toma pasivamente, en lugar de hacer o de vivir" 35 . Mientras, el minimalismo se ahoga en su propia mercancía isormorfa sin remedio. Esta música obliga a ser consumida con pasividad: no hay posibilidad de interacción.

"Las instituciones le originan necesidades (al hombre) que inmediatamente satisfacen sin que en éste medie la reflexión o el distanciamiento necesarios para poder elegir por sí mismo. No hay libertad". El mundo sonoro de Koyaanisqatsi, frenético en planteamiento, clama por procesos aditivos y adictivos continuos. Toda la música, uniformemente acelerada, no hace concesiones ni al reposo ni a la reflexión. Ya que la música parece no decir nada a priori, obliga al espectador a aceptar esa "nada". Impone un vacío lleno de chatarra sintética. "Se trata no sólo de ejercer coerción física sobre el otro, sino de ir hasta sus entrañas" añade Illich a su comentario anterior ${ }^{36}$.

El propio tono apocalíptico de la banda sonora está en proporción directa con el estilo literario de Illich: nuestro autor, a no ser que un cambio radical ocurra, prevé la extinción o una especie de "supervivencia compulsiva en un infierno planificado y mecanizado"37. Ese infierno toma vida en la música de Koyaanisqatsi.

Resulta también interesante realizar una comparación entre la música de Philip Glass y su amigo y colaborador en Koyaanisqatsi, Allen Ginsberg. Aunque de por sí la música minimalista es la antítesis de cualquier obra literaria, se observa una tendencia a la repetición en diversas poesías del principal valedor de la generación beat, de la misma manera que el mundo presentado por Koyaanisqatsi parece encontrarse retratado idénticamente en varias de las poesías de Ginsberg, sobre todo en las que forman parte de La caída de América (1973). En el ejemplo que exponemos a continuación se observan esas características de vigor incesante, aceleración continua y reiteraciones del mismo motivo de las que tanto hemos hablado a propósito de la música de Philip Glass: “¡Santo! ¡Santo! ¡Santo! ¡Santo! ¡Santo! ¡Santo! ¡Santo! ¡Santo! ¡Santo! ¡Santo! ¡Santo! ¡Santo! ¡Santo! ¡Santo! ¡Santo! ¡Santo! ¡Santo! (...) ¡Santas las soledades de rascacielos y aceras! ¡Santas las cafe-

34 El significado expandido de este término, para nuestro autor, es muy amplio: desde la burocracia al propio lenguaje médico, justicia o internet.

35 AA.VV: La educación. Autocrítica de Paulo Freire e Iván Illich, Buenos Aires, Búsqueda de Ayllu, 2001 pág 15.

36 ILLICH, I.: Némesis médica. La expropiación de la salud .México, Pantheon Books, 1976.

37 AA.VV: Op. Cit, pág 15. 
terías atestadas por los millones! ¡Santos los misteriosos ríos de lágrimas que corren bajo las calles!"38

El mayor problema viene a la hora de tratar a Guy Debord. Éste presenta, en sus distintos libros y escritos, un aluvión de feroces críticas a la sociedad actual que solo podría ser aprehendido con un profundo estudio de la interpretación que de Debord se ha hecho en el film. Aquí nos hemos limitado a poner de relieve, aún superficialmente, ciertos nexos de unión.

Si en tesis como ésta: "En el espectáculo, (...) el fin no es nada y el desarrollo lo es todo. El espectáculo no conduce a ninguna parte salvo a sí mismo"39, cambiamos el término espectáculo por "música minimalista" la frase mantendría su sentido. La música de Glass y el minimalismo se convierten, de este modo, en parte del espectáculo.

La crítica en genérico a la mercancía es expresada en La sociedad del espectáculo (1963) en términos antinómicos a lo cualitativo: "lo que ella desarrolla es lo cuantitativo, y sólo en lo cuantitativo puede desarrollarse" 40 . La música de Philip Glass parece convertirse, de hecho, en términos de la tabla de multiplicar mientras que los módulos parecen adquirir, por sincronización con el universo fílmico, entidad material y mercantil. Lo cuantitativo y masivo definen, gracias en parte a esta característica inherente de la banda sonora, el universo de Reggio en Vessels o The Grid41.

Incluso en los capítulos que el líder del situacionismo dedica al tiempo espectacular, observamos como éste queda expresado o incluído, en sus tesis más básicas, en el mismo concepto temporal que la partitura plantea. "Las sociedades estáticas organizan el tiempo (...) según el modelo cíclico".El tiempo cíclico de los procesos minimalistas niega, como ya dijimos, el tiempo orgánico en los mismos términos que Debord: "una serie de instantes falsamente individualizados", "una falsa conciencia del tiempo"42. La sociedad del espectáculo añade que se trata del "puro retorno del tiempo a un mismo lugar, la repetición de una serie de gestos"43. [10] ¿Qué es el minimalismo al fin y al cabo?

Interesante resulta analizar la impresionante secuencia de Pruit Igoe usando

38 GINSBERG, A.: Aullido y otros poemas. Madrid, Visor de Poesía, 200, pág. 41.

39 DEBORD, G.: La sociedad del espectáculo. Valencia, Pre-textos, 1999, Tesis 14,pág 42,

40 Ibídem. pág. 52, (Tesis 38).

41 Precisamente, la crítica básica de Leopoldo Kohr -economista muy valorado por Reggio- es dirigida a la masificación y aplicación sistemática a gran escala de cualquier procedimiento urbanístico, económico, tecnológico o industrial. Esta y otras críticas, así como propuestas de cambio, serían recogidas por el discípulo de Kohr, SCHUMACHER, EF (1973) en Lo pequeño es hermoso. Madrid, Tursen/Hermann Blume, 2001. de Kohr, SCHUMACHER, E.F (1973) en Lo pequeño es hermoso. Madrid, Tursen/Hermann Blume, 2001. en Koyaanisqatsi por doquier gracias a la música e ima-

42 Ibídem., pág. 134, (Tesis 149) 

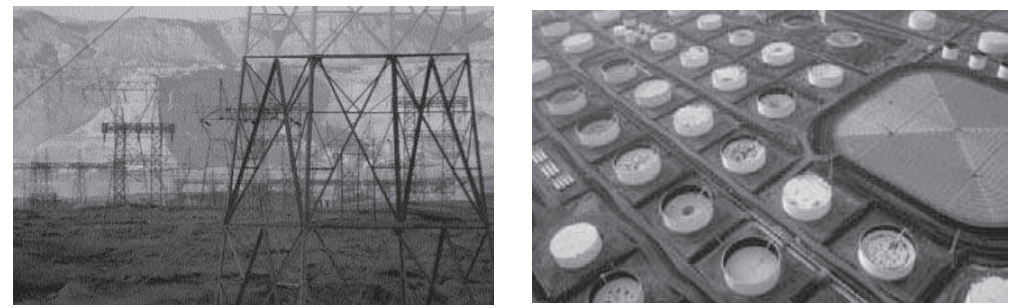

10. El gigantesco decorado de la ciudad, sometido a cámaras rápidas, nos desvela una nueva percepción temporal.

11. Toma aérea parcial del malogrado Pruit Igoe antes de su demolición.

como pretexto el diálogo que subyace entre las críticas urbanísticas de Debord y la siempre constante y homogénea música de Philip Glass. El barrio residencial de Pruit Igoe (1956-1973) fue el mayor fracaso urbanístico de la historia de los Estados Unidos. Realizado en San Luis por el arquitecto Minoru Yamasaki (el arquitecto de las Torres Gemelas), intentó ser un ejemplo de urbanización megalómana en la vía de los proyectos de Le Corbussier. No se tuvieron en cuenta los factores humanos, ni creativos, ni medioambientales..., es decir, no se tuvieron en cuenta los factores urbanísticos principales. Dados los índices de suicidios, violencia y marginación, se tomó la decisión de eliminar Pruit Igoe [11].

Las imágenes de archivo nos acercan, por tomas aéreas, a una gran superficie de edificios -como los de cualquier ciudad- seriados. La afirmación de que "el aislamiento de la población por medio del urbanismo se ha revelado una forma de control mucho más eficaz ${ }^{44 "}$ es el preludio debordiano. Glass responde con una música contenida por las cuerdas, dramática, proyectada en las solitarias imágenes llenas de residuos urbanos. "La miseria formal, así como la gigantesca extensión de esta nueva experiencia del habitat, proceden ambas de su carácter masivo implícito (...) en las condiciones modernas de construcción", añade Debord en su siguiente tesis. A ello responde Glass con la aparición repentina y frenética de un sintetizador reforzado en los bajos: una vasta masificación de chatarra. Ello se completará con el griterío de las muchedumbres solitarias, expresas en las voces desconsoladas del coro. La miseria queda retratada apocalípticamente por la imagen y el tono general de las notas. El volumen de los instrumentos se hace eco del gigantismo del proyec-

\footnotetext{
43 Ibídem., pág. 118, (Tesis 127).

44 Ibídem., pág. 146, (Tesis 172).
} 
to de Pruit Igoe y del de su fracaso. Las escalas descendentes y consecutivas, mientras tanto, definen la caída de los gigantescos bloques de edificios.

\section{BREVE CONCLUSIÓN.}

En ningún momento Philip Glass hizo una obra distinta a lo que ya había realizado en composiciones anteriores. Se limitó a repetir, grosso modo, las mismas fórmulas y características. ¿Cómo es posible entonces llegar a la conclusión de que solamente su partitura puede dirigir, estructurar, describir y definir Koyaanisqatsi a la perfección? ¿Cómo puede existir un diálogo entre los ideólogos y su música si no hay una intención implícita?

La respuesta es sencilla, y se encuentra, sobre todo, en los dos últimos apartados de este artículo: El minimalismo es uno de los fenómenos culturales que mejor mimetiza nuestro nuevo orden. La crítica que de ese orden hacen estos ideólogos es universal y, por tanto, la esencia de la música de Glass queda fuertemente contenida en esa crítica. Dicha música expresa en el film lo inexpresable de nuestro estado actual.

FICHA TÉCNICA BASICA.

Koyaanisqatsi (EEUU, 1982). 86 minutos, color.

Director: Godfrey Reggio. Producción: Francis Ford Coppola.

Productora: IRE

Guión: Ron Fricke, Godfrey Reggio, Michael Hoenig y Alton Walpole Inspiración e ideas: Jacques Ellul, Ivan Illich, Guy Debord y Leopoldo Kohr Fotografía y montaje: Ron Fricke, Alton Walpole.

Música: Philip Glass Producción: Kurt Munkacsi. Dirigida por: Michael Riesman Ingeniero de Sonido: Michael Stocker Efectos musicales: David Rivas 